\title{
Kpamkue cooбuенuя
}

УдК 578.841.1:577.113

\section{ЛОКАЛИЗАЦИЯ ФУНКЦИОНАЛЬНО ВАЖНЫХ ОБЛАСТЕЙ ГЕНОМА ВИРУСА ЯДЕРНОГО ПОЛИЭДРОЗА БОЛЬШОЙ ВОЩИННОЙ МОЛИ НА ФИЗИЧЕСКОЙ КАРТЕ ГЕНОМА}

\author{
В. А. Мордвинов, И. Х. Урманов, Н. Г. Холодилов, И. В. Никонов
}

При исследовании структуры генома бакуловирусов нами был изучен характер гидролиза ДНК вируса ядерного полиэдроза большой вощинной моли эндонуклеазами рестрикции, проведено клонирование в клетках Escherichia coli EcoRI- и BamHI-фрагментов этой ДНК в составе плазмид $p S F 124$ и $p B R 322$ [1]. При трансформации клеток насекомых $S C L d-135$ гибридными плазмидами, несущими индивндуальные фрагменты вирусной ДНК: EcoRI-O размером $1,39 \cdot 10^{8}$ и $B a m H I-H$ размером $0,60 \cdot 10^{\circ}$, было показано, что эти фрагменты (из многих других испытанных) содержат нуклеотидные последовательности, способные выполнять роль огі-района генома вируса [2].

Проведено клонирование $E c o R I$-фрагментов вирусной ДНК в клетках $E$. coli в coставе вектора $p S K$, имеющего делецию в области промотора гена устойчивости к тетрациклину [3]. Это позволило выявить, что EcoRI-R-фрагмент вирусной ДНК может выполнять роль промотора в прокариотической системе (клетки, трансформированные гибридной плазмидой с $R$-фрагментом, растут на среде, содержащей тетрациклин).

Для локализации на физической карте вирусного генома функционально активных областей мы воспользовались данными работы [4], в которой показано, что BamHI-

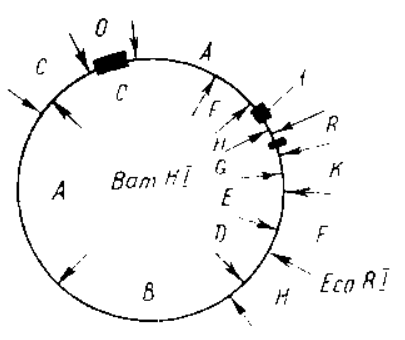

\begin{abstract}
Локализация функционально активных областей (1) на физической карте генома вируса ядерного полиэдроза больщой вощинной моли. Стрелками указаны сайты рестрикции ДНК эндонуклеазами BamHI (внутри) и EcoRl (снаружи).

Localization of functionally active regions (1) on the physical map of nuclear polyhedrosis virus genome Galleria mellonella. The arrows show site of DNA restriction by BamHI (inside) and EcoRI (outside) endonucleases.
\end{abstract}

фрагменты вирусной ДНК следуют друг за другом в следующем порядке (геном представлен в линейной форме): $A$ (размером $\left.26,1 \cdot 10^{6}\right)-C\left(17,09 \cdot 10^{6}\right)-F\left(2,4 \cdot 10^{6}\right)-H$ $\left(0,6 \cdot 10^{6}\right)-G\left(2,03 \cdot 10^{6}\right)-E\left(4,14 \cdot 10^{6}\right)-D\left(6,5 \cdot 10^{6}\right)-B\left(21,81 \cdot 10^{8}\right)$. Для локализации активных фрагментов $E c o R I-O$ и $E c o R I-R$ провели дополнительное картирование. Вирусную ДНК гидролизовали одновременно двумя рестриктазами BamHI и EcoRI. Препаративно выделили индивидуальные BamHI-фрагменты генома и гидролизовали каждый из них ферментом EcoRI. Сопоставление картин электрофоретического разделения в агарозном геле продуктов этих различных гидролизов и определение размеров фрагментов позволило картировать изучаемые фрагменты на BamHI-карте генома (рисунок).

Оказалось, что фрагмент $E c o R I-O\left(1,39 \cdot 10^{6}\right)$ расположен в BamHI-фрагменте $C$; фрагмент EcoRI-R $\left(0,85 \cdot 10^{\circ}\right)$ - в BamHI-фрагменте G. EcoRI-фрагменты $O$ и $R$ разделены фрагментом EcoRI-A $\left(10,67 \cdot 10^{6}\right)$. Следовательно, фрагменты BamHI-H и EcoRI-O, содержашие «области огі», разделены довольно большим участком генома $\left(\sim 10 \cdot 10^{\text {f }}\right)$. На EcoRI-карте активные фрагменты соседствуют (кроме $A$ ) еще с такими фрагментами: $O$ с $C\left(8,17 \cdot 10^{6}\right)$, а $R$ с $K\left(2,32 \cdot 10^{6}\right)$. 
LOCALIZATION OF FUNCTIONALLY IMPORTANT GENOME

REGIONS OF THE GALLERIA MELLONELLA L. NUCLEAR POLYHEDROSIS VIRUS ON THE !HYSICAL MAP OF THE VIPAL GENOME

V. A. Mordvinov, I. Kh. Urmanov, N. G. Kholodilov, I. V. Nikonov

Institute of Molecular Biology, Koltsovo, Novosibirsk

S u m m a r y

Three regions are localized on the physical DNA map using BamHI and EcoRI restriction endonucleases. Two regions have or $i$ function and the third one possesses a promoter function in the procaryotic system.

1. Анализ ДНК вируса ядерного полиэдроза большой вошинной моли с помощью эндонуклеаз рестрикции и ее клонирование в клетках E. coli/B. A. Мордвинов, И. Х. Урманов, Н. Г. Холодилов, А. А. Ильичев.-Молекуляр. биология, 1983, вып. 34, c. $70-73$.

2. Nucleotide sequence of the Galleria mellonella NPV origin of DNA replication / V. M. Blinov, V. V. Gutorov, N. G. Holodilov et al.-FEBS Lett., 1984, 167, N 2, p. $254-258$

3. Конструирование и свойства вектора для клонирования промоторсодержащих фрагментов ДНК. Клонирование промоторов $E$. coli и бактериофага $T 7 / O$. И. Серпинский, Е. А. Каргинова, Н. Н. Микрюков и др.-- Биоорган. химия, 1982, 8, № 6, c. $840-847$.

4. Урманов И. X., Кравченко В. В. Характеризация генома вируса ядерного полиэдроза Galleria mellonella с помощью эндонуклеаз рестрикции. Картирование мест расщепления BamHI на кольцевой ДНК вируса.-В кн.: Структура и функции плазмид: Тез. докл. V. Всесоюз. совещ. по прогр. «Плазмида». М., 1980, с. 215.

ВНИИ молекуляр. биологии

Главмикробиопрома при СМ СССР,

Получено 22.01 .85

пос. Кольцово Новосибирской обл.

удК 577.152 .611

МОДИФИКАЦИЯ ФЕНИЛАЛАНИЛ-ТРНК-СИНТЕТАЗЫ ИЗ $E$. COLI С ПОМОЩЬЮ 1,N6

\author{
В. Н. Подует, Г. А. Невинский, О. И. Лаврик
}

Введение, 1, $\mathrm{N}^{6}$-Этеноаденозин-5'-трифосфат ( $\left.\mathrm{ATP}\right)^{*}$ широко исп'ользуется для изучения различных нуклеотидзависимых ферментов [1], в том числе и для исследования АТРузнающих участков аминоацил-тРНК-синтетаз [2, 3] как в качестве флюоресцируюшего аналога субстрата, так и флюоресцентной метки. БАТР является субстратом в реакции аминоацилирования тPHK, катализируемой фенилапанит-тРНК-синтетазой из E. coli [2].

В литературе отсутствуют данные о зависимых от УФ-света преврашениях этенированных нуклеотидов. В то же время ГАТР по сравнению с АTP хорошо поглощает свет в области $300-350$ нм. Это обстоятельство позволи. ио нам надеяться на возбуж:дение молекулы этенонуклеотида монохроматнческим свстом азотного лазера с длиной волны 337 нм с последующим ковалентным присоединением аналога нуклеотида к белку. Возможность подобного введения метки в белок представляется особенно перспективной ввиду того, что белки практически пе поглочают свет с длиной волны выше 300 нм.

В связи с этим в работе исследована возможность прямого фотоприсоединения SATP к фенилаланил-тРНК-синтетазе $E$. coli под действием монохроматического света азотного лазера.

Материалы и методы. Фенилаланил-тРНК-синтетаза из $E$. coli MRE-600 была выделена, согласно [4]. тPHK из E. coli MRE-600 была получена, согласно [5]. ATP, L-фенилаланин фирмы «Reanal», Венгрия. L-[14 C]-фенилаланин (360 Ки/моль) -

* Здесь и далее вместо ऽАТР следует читать єАТР. 